\title{
Penegakan Hukum Pelaku Tindak Pidana Pelecehan Seksual terhadap Perempuan di Moda Transportasi Umum Konvensional
}

\author{
Galih Bagas Soesilo1*, Muh. Alfian², Amalia Fadhila Rachmawati ${ }^{3}$ \\ 1 Fakultas Ilmu Sosial Universitas Muhammadiyah Purworejo, Indonesia \\ 2 Fakultas Ilmu Sosial Universitas Muhammadiyah Purworejo, Indonesia \\ 3 Fakultas Ilmu Sosial Universitas Muhammadiyah Purworejo, Indonesia \\ *Corresponding Author: galihbagas@umpwr.ac.id
}

\begin{tabular}{|c|c|}
\hline History Artikel & Abstrak \\
\hline $\begin{array}{l}\text { Masuk: } 14 \text { Agt } 2021 \\
\text { Review: } 10 \text { Sep } 2021 \\
\text { Diterima: } 12 \text { Okt } 2021 \\
\text { Terbit: } 19 \text { Okt } 2021\end{array}$ & $\begin{array}{l}\text { Transportasi merupakan komponen utama dalam sistem } \\
\text { hidup dan kehidupan, sistem pemerintahan, dan sistem } \\
\text { kemasyarakatan. Koalisi Ruang Publik Aman (KRPA) merilis } \\
\text { hasil Survei Nasional Pelecehan Seksual di Ruang Publik, } \\
\text { menunjukkan bahwa moda transportasi umum adalah } \\
\text { lokasi kedua tertinggi terjadinya pelecehan seksual di ruang } \\
\text { publik. Penelitian ini secara komrehensif bertujuan untuk } \\
\text { mengetahui jenis atau bentuk Pelecehan seksual dimoda } \\
\text { trasportasi umumkhususnya yang berbasis Non-Online atau } \\
\text { bersifat konvensional, dan untuk mengetahui bagaimana } \\
\text { hukum, sebagai alat rekayasa sosial memerankan perannya } \\
\text { guna memberikan perlindungan maksimal dengan } \\
\text { dijeratnya pelaku tindak pidana tersebut. Penelitian ini } \\
\text { menggunakan metode penelitian hukum normatif, karena } \\
\text { mengkaji dan menganalisis berbagai peraturan perundang- } \\
\text { undangan di Indonesia. Data yang digunakan adalah data } \\
\text { sekunder, dengan analisis data menggunakan metode } \\
\text { kualitatif. Hasil penelitian ini menunjukan bahwa bentuk } \\
\text { pelecehan yang sering terjadi di transportasi umum berupa } \\
\text { mengambil gambar/ foto/ vidio secara diam-diam, siulan } \\
\text { atau suara atau gerak tubuh yang mengekspresikan } \\
\text { kejahatan kesusilaan seperti gestur vulgar, dipertontonkan } \\
\text { masturbasi diperlihatkan hingga disentuh, diraba, dan } \\
\text { digesekdengan kelamin. Pelecehan seksual merupakan jenis } \\
\text { perbuatan cabul yang diatur pada Pasal } 289 \text { sampaidengan } \\
\text { 296 KUHP dan Undang- undang ITE serta Undang-undang } \\
\text { hak cipta apabila mengambil gambar/ foto/ vidio secara } \\
\text { diam-diam. Adapun langkah-langkah penanggulangan yaitu } \\
\text { untukselalu waspada dengan segala bentukpelecehan. Bagi } \\
\text { sesama pengguna agar berperan aktif apabila melihat } \\
\text { kejahatan tersebut. Sementara untuk penyedia jasa } \\
\text { transportasi publik harus memiliki komitmen dan langkah } \\
\text { nyata untuk memberikan kenyamanan dan perlindungan } \\
\text { lebih terutama bagi perempuan supaya tidak menjadi }\end{array}$ \\
\hline
\end{tabular}




\section{Ahmad Dahlan \\ Legal Perspective \\ Volume 01, Issue 02, 2021, pp. 145-154

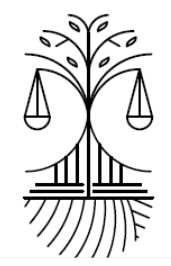

\begin{tabular}{|c|c|}
\hline & $\begin{array}{l}\text { korban pelecehan seksual dimoda trasportasi umum } \\
\text { berbasis Non-Onlineatau bersifatkonvensional. } \\
\text { Kata Kunci: Jerat Hukum; Pelecehan Seksual; Transportasi } \\
\text { Umum }\end{array}$ \\
\hline Article's History & Abstrack \\
\hline $\begin{array}{l}\text { Received: } 14 \text { Agt } 2021 \\
\text { Reviewed: } 10 \text { Sep } 2021 \\
\text { Accepted: } 12 \text { Okt } 2021 \\
\text { Published: } 19 \text { Okt } 2021\end{array}$ & $\begin{array}{l}\text { Transportation is a significant component in life and living } \\
\text { systems, government systems, and social systems. The } \\
\text { Coalition for SafePublic Spaces (KRPA) released the results of } \\
\text { the National Survey of Sexual Harassment in Public Spaces, } \\
\text { showing that public transportation is the second-highest } \\
\text { location for sexual harassment in public spaces. This } \\
\text { comprehensive research aims to find outthe types or forms of } \\
\text { harassment in publictransportation, especiallythose based on } \\
\text { non-online or conventional ones, and to find out how the law, } \\
\text { as a social engineering tool, is played to take advantage of } \\
\text { maximum protection by ensnaring the perpetrators of the } \\
\text { crime. This study uses normative legal research methods } \\
\text { because it examines and analyzes various laws and } \\
\text { regulations in Indonesia. The data used is secondary data, } \\
\text { with data analysis using qualitative methods. The results of } \\
\text { this study indicate that the forms that often occur in public } \\
\text { transportation are pictures/photos/videos secretly, whistles } \\
\text { or sounds or gestures that express decency crimes such as } \\
\text { vulgar gestures, masturbation is shown to be touched, } \\
\text { touched, andrubbed with the genitals. Sexual harassment is a } \\
\text { type of obscene act regulated in Articles } 289 \text { to } 296 \text { of the } \\
\text { Criminal Code and the ITE Law and the Copyright Law when } \\
\text { secretly taking pictures/photos/videos. The countermeasures } \\
\text { are always to be vigilantwithall formsofview, forfellow users } \\
\text { to play an active role when they see the crime. Meanwhile, } \\
\text { public transportation service providers must have real } \\
\text { commitments and steps to provide more comfort and } \\
\text { protection, especially for women, so as not to become victims } \\
\text { of sexual transportation in non-line-based or conventional } \\
\text { publictransportation modes. }\end{array}$ \\
\hline
\end{tabular}

Keywords: Snares of Law; Sexual Harassment; Public Transportation

All articles are published online in http://journal2.uad.ac.id/index.php/adlp/

\section{Pendahuluan}

Permasalahan terkait dengan pelayanan publik telah menjadi perhatian dan keprihatinan baik itu ditingkat pemerintahan daerah maupun pemerintahan pusat. Permasalahan tersebut diantaranya yang kita ketahui bersama ialah banjir, kepadatan penduduk, masalah tata ruang, hingga masalah kemacetan. Namun 
kemacetan sekarang ini menjadi masalah utama di bidang transportasi publik (Ariesandi et al., 2020). Transportasi merupakan komponen utama dalam menompang berbagai lini kehidupan. Tingkat kepadatan penduduk akan memiliki pengaruh signifikan terhadap kemampuan transportasi melayani kebutuhan masyarakat. Maka dari itu, Kondisi sosial demografis wilayah memiliki pengaruh terhadap kinerja transportasi di wilayah tersebut.

(Aminah, 2007). Rasa aman, nyaman saat bertrasportasi adalah hak untuk semua orang tanpa terkecuali. Terlebih lagi untuk masyarakat yang menggunakan moda transportasi publik.

Kenyamanan dan keamanan bagi seluruh pengguna moda transportasi publik haruslah ditingkatkan. Berdasarkan data yang dikeluarkan Koalisi Ruang Publik Aman (KRPA) merilis hasil Survei Nasional Pelecehan Seksual di Ruang Publik yang hasilnya cukup mencengangkan. Hasil survei tersebut menunjukkan bahwa moda transportasi umum menjadi lokasi kedua tertinggi terjadinya pelecehan seksual di ruang publik. Sementara untuk lokasi tertinggi pertama terjadinya pelecehan seksual berada di jalan umum. Lebih rinci lagi bahwa dari analisis data survei tahun 2018, KRPA menemukan dan menunjukan sebanyak 46.80\% responden mengaku pernah mengalami pelecehan seksual di transportasi umum. Sebanyak 35,8\% responden mengalami pelecehan di bus. Angkot mengikuti dengan 29,49\% responden yang mengaku pernah dilecehkan di transportasi tersebut. Pada survei yang sama tahun lalu, KRPA menemukan 3 (tiga) dari 5 (lima) perempuan pernah mengalami pelecehan seksual di ruang publik(Yosepha Pusparisa, 2019).

Bagi Korban kejahatan seksual cenderung menimbulkan dampak negatif, yang menyerang secara fisik, psikologis, dan juga sosial. Namun untuk jenis kejahatan Pelecehan seksual biasanya korban mengalami traumatik secara psikologis yaitu seperti (M. Anwar Fuadi, 2011):

1. Perasaan tertekan, depresi, hilangnya rasa percaya diri, trauma bahkan hingga gangguan jiwa.

2. Dampak jangka pendek secara psikologis, biasanya korban merasa bersalah sangat marah, jengkel, merasa bersalah, malu dan terhina, kadang-kadang gangguan ini bisa menyebabkan insomnia dan kehilangan nafsu makan. Dampak jangka panjang, biasanya dapat berupa sifat atau pesepsi yang negatif terhadap diri sendiri maupun terhadap laki-laki, dampak ini terjadi apabila korban tidak mendapatkan penanganan dan bantuan yang memadai.

Data dari Koalisi Ruang Publik Aman (KRPA) sebenarnya telah mengindikasikan bahwa tingkat pelecehan seksual terhadap perempuan, khususnya dalam hal pelecehan seksual di moda Transportasi Umum masih sangatlah tinggi. Oleh karena itu, berdasarkan latar belakang telah dipaparkan 


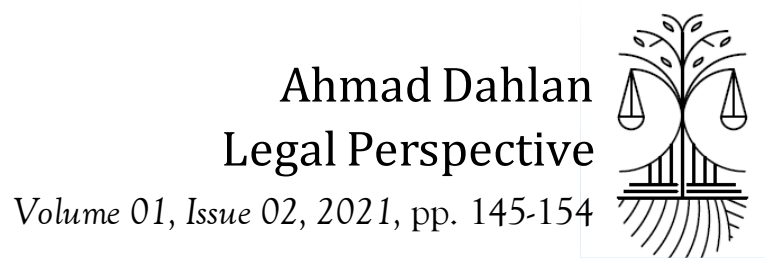

diatas, mendorong kami penulis untuk menelaah lebih dalam tentang bagaimana pertanggungjawaban pelaku tindak pidana pelecehan seksual terhadap perempuan di moda transportasi umum.

\section{Metodologi}

Penentuan metode penelitian dipandang penting, karena ada hubungan erat antara jenis penelitian dengan sistematika dan metode. Serta analisis data guna mencapai nilai validasi yang tinggi baik data yang dikumpulkan maupun hasil akhir penelitian (Suratman \& Dillah, 2013). Peneltian ini berfokus pada penelitian hukum normatif karena mengkaji dan menganalisis berbagai peraturan perundang- undangan di Indonesia. Oleh karena itu untuk memperoleh hasil penelitian, data yang dipergunakan adalah data sekunder (Ishaq, 2017). Kemudian bahan hukum yang digunakan diantaranya adalah bahan hukum primer yaitu peraturan perundang-undangan, bahan hukum sekunder yaitu buku dan jurnal yang secara khusus membahas tentang penegakan hukum terhadap pelaku pelecehan seksual, selain itu penulis juga menggunakan bahan hukum tersier yaitu artikel maupun berita yang terkait berasal dari internet sebagai pelengkap bahan hukum dalam penelitian ini. Keseluruhan bahan tersebut diuraikan dalam bentuk kalimat yang efektif, kemudian dianalisis guna memecahkan permasalahan yang diteliti. Analisis data dalam penelitian ini menggunakan metode kualitatif. Metode kualitatif yaitu menguraikan data dalam bentuk kalimat yang teratur, runtun, logis, dan tidak tumpang tindih (Sugiyono, 2008).

\section{Hasil dan Analisis}

\section{Tinjauan Umum Tentang Kejahatan Seksual}

Kejahatan terhadap kesusilaan menjadi salah satu permasalahan hukum yang marak terjadi didalam tananan kehidupan bermasyarakat. Salah satu kejahatan terhadap kesusilaan yang sangat keji ialah kekerasan seksual dalam bentuk pemerkosaan. Kejahatan pemerkosaan tidak hanya terjadi diperkotaan, dijalanan, ataupun di tempat yang menjadi potensial menurut stigma masyarakat. Melainkan mungkin terjadi pula di wilayah privat seperti di rumah ataupun sekolah. Kejahatan seksual sebagai salah satu bentuk kekerasan terhadap perempuan berbasis gender, tidak selalu berupa pemerkosaan. Menurut Poerwandari, kejahatan atau kekerasan seksual mengandung aspek bernuansa kekerasan seperti ancaman, pemaksaan, atau kekerasan fisik, sehingga kejahatan seksual juga dapat berbentuk pelecehan seksual atau serangan seksual.

Gender based violence adalah istilah yang merujuk kepada kekerasan yang melibatkan laki-laki dan perempuan, biasanya yang menjadi korban adalah perempuan, sebagai akibat adanya distribusi kekuasaan yang timpang antara laki-laki dan perempuan. 


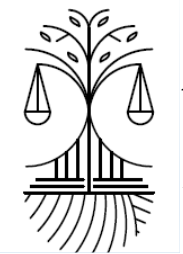

Ahmad Dahlan

Legal Perspective

Volume 01, Issue 02, 2021, pp. 145-154

Berdasarkan ruang lingkupnya, kekerasan terhadap perempuan dapat dibagi menjadi tiga jenis, yaitu (Susiana, 2012):

1. Kekerasan dalam wilayah keluarga (domestic violence);

2. Kekerasan dalam wilayah publik atau masyarakat (public domain); dan

3. Kekerasan yang dilakukan oleh negara (state).

Hal yang tidak bisa diterima ialah adanya cara pandang patriarki, yang sering mengatakan bahwa korban merupakan pemicu terjadinya tindak kekerasan seksual (Fatura, 2019). Menurut Martha pada buku perempuan kekerasan dan hukum, mengatakan bahwa perempuan berada pada posisi yang marginal atau kurang diuntungkan atau mendapat posisi yang lebih rendah dari laki-laki, baik saat berada pada ruang publik atau diruang privat. Strata budaya patriarki dimasyarakat menjadi faktor utama, menjadikan perempuan sebagai kaum minoritas sehingga menyebabkan adanya pemahaman bahwa laki-laki memiliki kuasa di ruang publik seperti politik dan dunia kerja sedangkan perempuan di ruang publik menepati posisi kedua, second class atau tersubordinat oleh laki-laki (Aroma Elmina, 2003). Menurut pemahaman Teori Hukum Feminis (Feminist Legal Theory) yang kemudian dikembangkan melaui kajian feminist juriprudence mengamati bahwa kondisi hukum yang masih belum berpihak pada korban perempuan terjadi karena dalam hukum memperlihatkan adanya keterbatasan atas realitas nilai sosial (Yazid Bustomi, 2020).

Pelecehan seksual merupakan perilaku menyimpang dari tatanan etis dalam berkehidupan, karena perbuatan tersebut secara tidak langsung memaksakan seseorang terlibat dalam suatu hubungan seksual atau menetapkan seseorang sebagai objek perhatian yang tidak diinginkannya. Artinya, bentuk pelecehan seksual dapat berupa sikap yang tidak senonoh, seperti menyentuh anggota tubuh yang vital dan dapat pula hanya berupa kata-kata atau pernyataan yang bernuansa tidak senonoh. Sedangkan orang yang menjadi objek sentuhan atau pernyataan dalam hal ini korban tersebut tidak menyenanginya. Jadi tidak semua pelecehan seksual harus berbentuk pemerkosaan atau pun pencabulan (Mariana \& Daya, 2020).

Hal serupa juga telah dijelaskan didalam Deklarasi PBB tentang penghapusan kekerasan terhadap perempuan (Declaration on the Elimination of Violence against Women). Pada Pasal 1 menyebutkan bahwa, yang dimaksud dengan kekerasan terhadap perempuan adalah setiap perbuatan berdasarkan perbedaan jenis kelamin yang berakibat atau mungkin berakibat kesengsaraan atau penderitaan perempuan secara fisik, seksual atau psikologis, termasuk ancaman perbuatan 


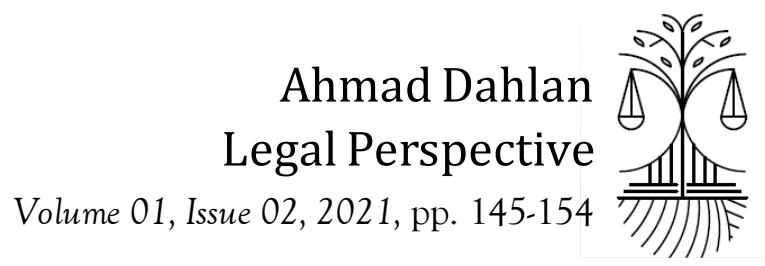

tertentu, pemaksaan atau perampokan kemerdekaan secara sewenang-wenang, baik yang terjadi di depan umum maupun dalam kehidupan pribadi (Hairi, 2015).

Guntoro Utamadi dan Paramitha Utamadi membagi kategori pelecehan seksual yang dipakai dalam dasar pengukuran dalam Sexual Experience Questionnaire (SEQ), yaitu dalam bentuk yang lebih tersistematis (Riri Novita Sari, Luluk Dwi Setiati, 2018):

1. Gender Harassment yaitu pernyataan atau tingkah laku yang bersifat merendahkan berdasarkan jenis kelamin.

2. Seductive Behaviour yaitu permintaan seksual tanpa ancaman, rayuan yang bersifat tidak senonoh atau merendahkan.

3. Sexual Bribery yaitu penyuapan untuk melakukan hal yang berbau seksual dengan memberikan janji akan suatu ganjaran.

4. Sexual Coercion yaitutekanan yang dis-ertai dengan ancaman untuk melakukan hal-hal yang bersifat seksual.

5. Sexual Assult yaitu serangan atau paksaan yang bersifat seksual, gangguan, । seksual yang terang-terangan atau kasar.

\section{$\underline{\text { Kejahatan Seksual Dalam KUHP }}$}

Kejahatan kesusilaan di dalam Kitab Undang-undang Hukum Pidana telah diatur dalam BAB XIV Buku II Kejahatan Terhadap Kesusilaan. Di mana dalam bab tersebut memuat pasal-pasal yang menjelaskan mengenai jenis-jenis kejahatan kesusilaan yang apabila diuraikan sebagai berikut:

1. Kejahatan melanggar kesusilaan umum (Pasal 281KUHP)

2. Kejahatan berkaitan dengan pornografi (Pasal 282 KUHP);

3. Kejahatan pornografi terhadap orang yang belum dewasa (Pasal 283 KUHP);

4. Kejahatan pornografi sebagai pencahariannya (Pasal 283 bis);

5. Kejahatan perzinahan (Pasal $284 \mathrm{KUHP}$ );

6. Kejahatan pemaksaan untuk bersetubuh/ pemerkosaan (Pasal 285 KUHP);

7. Kejahatan bersetubuh dengan perempuan di luar kawin yang dalam keadaan

8. pingsan atau tidak berdaya (Pasal 286 KUHP);

9. Kejahatan bersetubuh dengan perempuan di luar kawin yang umurnya belum

10. 15 tahun (Pasal 287 KUHP);

11. Kejahatan bersetubuh dengan perempuan dalam perkawinan yang belum

12. waktunya dikawin dan menimbulkan akibat luka-luka (pasal 288 KUHP);

13. Kejahatan perkosaan berbuat cabul atau perbuatan yang menyerang

14. kehormatan kesusilaan (pasal 289 KUHP);

15. Kejahatan perbuatan cabul pada orang yang pingsan, pada orang yang

16. umurnya belum 15 tahun atau belum waktunya dikawin (Pasal 290 KUHP);

17. Kejahatan perbuatan cabul sesama kelamin, pada orang yang belum dewasa 


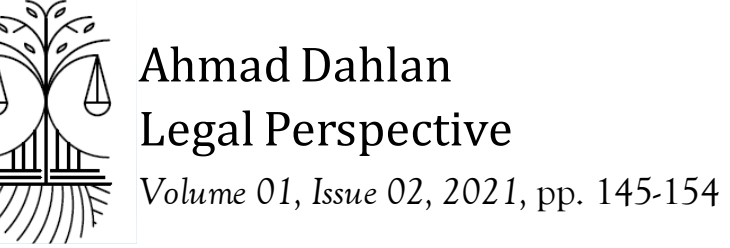

18. (Pasal 292 KUHP);

19. Kejahatan menggerakkan orang untuk berbuat cabul dengan orang yang

20. belum dewasa (pasal $293 \mathrm{KUHP}$ );

21. Kejahatan berbuat cabul dengan anaknya, anak dibawah pengawasannya dan

22. lain-lain yang belum dewaasa (Pasal 294 KUHP);

23. Kejahatan pemudahan berbuat cabul bagi anaknya, anak tirinya dan lain-lain

24. yang belum dewasa (pasal $295 \mathrm{KUHP}$ );

25. Kejahatan pemudahan berbuat cabul sebagai mata pencaharian atau

26. kebiasaan (pasal 296 KUHP);

27. Kejahatan memperdagangkan wanita dan anak laki-laki yang belum dewasa

28. (Pasal 297 KUHP);

29. Kejahatan mengobati wanita dengan menimbulkan harapan bahwa hamilnya

30. dapat digugurkan (Pasal 299 KUHP).

\section{Ancaman Pidana Pelaku Pelecehan Seksual}

Siapapun berpotensi menjadi korban pelecehan seksual dimoda transportasi umum konvensional, baik Perempuan ataupun laki-laki. Kejahatan ini pada dasar tidak pilih-pilih namun dalam penekanan ini, perempuan sangatlah rentan menjadi korban kekerasan. Saat menjadi korban, segala hal dijadikan sebagai umpan penyebab terjadinya hal yang tidak diinginkan tersebut hingga menyudutkan korban. Dalam kasus pelecehan seksual selalu menyangkutpautkan masalah konsep moralitas yang ada di masyarakat. Maksudnya ialah perempuan dianggap sebagai simbol kesucian serta kehormatan (Perempuan, 2020).

Pelecehan seksual yang sering terjadi di transportasi umum dilakukan dalam berbagai bentuk perbuatan, yaitu berupa mengambil gambar/ foto/vidio secara diam-diam pada anggota tubuh atau bagian dari anggota tubuh yang halayak umum telah dianggap menjadi ruang privasi. Selanjutnya pelecehan seksual dapat berbentuk siulan atau suara atau gerak tubuh yang mengekspresikan kejahatan kesusilaan seperti gestur vulgar, dipertontonkannya masturbasi hingga disentuh, diraba, dan digesek dengan kelamin.

Di dalam KUHP tidak mengenal istilah perbuatan seksual, tetapi dikenal dengan perbuatan cabul yang diatur pada Pasal 289 sampai dengan 296 KUHP. Untuk tindak pidana perbuatan cabul, R.Soesilo dalam bukunya 'KUHP Serta KomentraKomentarnya' menyebutkan bahwa istilah 'perbuatan cabul' diartikan sebagai perbuatan yang melanggar rasa kesusilaan, atau perbuatan lain yang keji, dan semuanya dalam lingkungan hawa nafsu birahi (R. Soesilo, 1995). Hukum pidana Indonesia secara garis besar mengklasifikasikannya dalam $\mathbf{5}$ jenis perbuatan cabul (Arif Maulana, 2020):

1. Perbuatan cabul dengan pemaksaan kekerasan; 


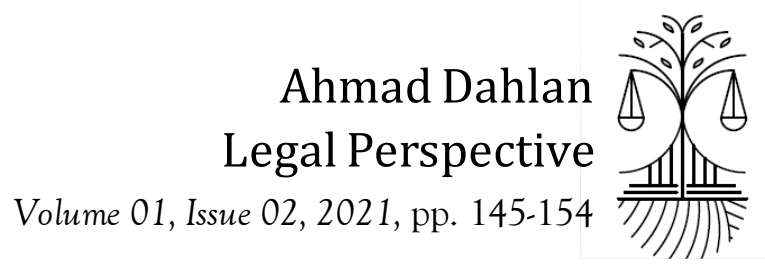

2. Perbuatan cabul terhadap orang yang tidak sadarkan diri;

3. Perbuatan cabul terhadap anak yang belum dewasa/belum cakap hukum;

4. Perbuatan cabul terhadap anak atau pun orang yang sedang dalam penguasaannya;

5. Perbuatan cabul pejabat terhadap bawahan kerja atau pun orang yang sedang dalam penguasaannya.

Salah satu bentuk pelecehan seksual dengan cara mengambil foto orang lain dalam hal ini tubuh secara diam-diam. Walau nampak hal yang terlihat biasa, namun apabila ditelaah lebih dalam, dapat ditemukan unsur pidana. Terlebih yang menjadi objek foto merupakan tubuh atau bagian tubuh yang merupakan privasi dari orang / objek foto tersebut. Hal ini diatur didalam ketentuan Pasal 19 ayat (1) Undang-undang Hak Cipta telah mengatur: "Untuk memperbanyak atau mengumumkan Ciptaannya, Pemegang Hak Cipta atas Potret seseorang harus terlebih dahulu mendapatkan izin dari orang yang dipotret". Atas perbuatan ini, maka pelaku dapat dijerat dengan ancaman pidana menurut Pasal 72 ayat (5) Undang-undang Hak Cipta dengan sanksi dipidana penjara paling lama 2 tahun dan/atau denda paling banyak Rp150.000.000. Jika foto atau video yang diambil tanpa izin tersebut yang memiliki muatan yang melanggar kesusilaan dan disebarluaskan melalui media elektronik, maka jeratan hukumnya ada di Pasal 27 ayat (1) Undang-Undang Nomor 11 Tahun 2008 tentang Informasi dan Transaksi Elektronik (UU ITE). Dengan ancaman hukuman pidana dengan pidana penjara paling lama 6 (enam) tahun dan/atau denda paling banyak Rp1.000.000.000,00 (satu miliar rupiah) sebagaimana ketentuan. Pasal 45 ayat (1) UU No. 19 tahun 2016 tentang Perubahan atas UU No. 11 tahun 2008 Tentang ITE.

\section{Kesimpulan}

Hukum untuk pelaku kejahatan seksual berupa pelecehan seksual telah lengkap untuk mengadopsi setiap tindak-tunduk prilaku yang diangkap sebagai bentuk asusila, baik yang diatur didalam ketentuan KUHP (Kitab Undang-undang Hukum Pidana) diatur dalam Pasal 281-299 bab XIV buku II maupun peraturan khusus yang ada diluar KUHP seperti Undang-undang Hak Cipta dan Undang-undang ITE. Penyedia trasoportasi publik dalam hal ini konvnsional, memiliki tanggung jawab untuk memastikan tersedianya kenyamanan dan keselamatan penumpang atau pengguna dari berbagai bentuk kejahatan maupun pelanggaran. Sesuai pernyataan sebelumnya, bahwa rasa aman, nyaman saat bertrasportasi adalah hak untuk semua orang tanpa terkecuali terlebih lagi kaum perempuan yang sering menjadi korban dengan menyangkutpautkan masalah konsep moralitas yang ada di masyarakat yaitu perempuan dianggap sebagai simbol kesucian serta 


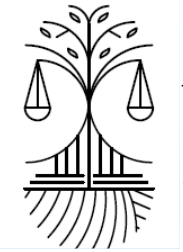

\section{Ahmad Dahlan}

Legal Perspective

Volume 01, Issue 02, 2021, pp. 145-154

kehormatan. Menurut kami sebagai peneliti, semestinya Penyedia jasa trasportasi publik dalam hal ini yang masih konvensional atau berbasis non-online secara umum, sepatutnya:

1. Untuk mulai mengadopsi atau meniru bagaimana model dan sistem keamanan yang ada pada moda trasportasi yang menggunakan berbasis online, seperti diletakannya atau tersedianya panic button atau tombol darurat yang mudah dijangkau oleh para penumpang. Fitur tersebut diharapkan memberikan rasa aman.

2. Untuk mulai mengadopsi model keamanan dengan kebijakan memisahkan tempat duduk penumpang, lelaki di bagian belakang dan perempuan di depan seperti kebijakan yang telah dibuat oleh PT Transjakarta.

3. Menyiapkan pos-pos pengaduan di halte bus atau terminal yang ditangani oleh aparat penegak hukum dan yang utama juga tersedianya Psikolog untuk menenagkan apabila terjadi kejahatan tersebut kepada korban. Tentunya peran dari pemangku kebijakan sangat diperlukan disini.

4. Masyarakat sesama pengguna moda trasportasi umum, harus memiliki peran aktif, apabila mengetahui adanya tindak pidana tersebut yaitu dengan menegur, memisahkan korban dan pelaku, serta melapor kepada petugas.

\section{Referensi}

Aminah, S. (2007). Transportasi Publik dan Aksesibilitas Masyarakat Perkotaan. Masyarakat, Kebudayaan Dan Politik, 20, 35-52.

Ariesandi, J. A., Resita, R., \& Salsbabila, Z. (2020). Kebijakan Transportasi Umum (Angkot) Untuk Menanggulangi Kemacetan Jalan. Jurnal Kebijakan Publik, 11(2), 77. https://doi.org/10.31258/jkp.11.2.p.77-82

Arif Maulana. (2020). Pemerasan Oknum Polri dalam Dugaan Kasus Asusila. Hukumonline.Com.

https://www.hukumonline.com/klinik/detail/ulasan/lt56cf0955ae82d/pe merasan-oknum-polri-dalam-dugaan-kasus-asusila/

Aroma Elmina, M. (2003). Perempuan Kekerasan dan Hukum. UII Pres.

Fatura, F. N. (2019). Telaah Tindak Pidana Pelecehan Seksual Secara Verbal Dalam Hukum Pidana Indonesia. Recidive, 8(3), 238-244.

Hairi, P. J. (2015). Problem Kekerasan Seksual: Menelaah Arah Kebijakan Pemerintah dalam Penanggulangannya. Negara Hukum, 6(1), 16.

Ishaq. (2017). Metode Penelitian Hukum Dan Penulisan Skripsi, Tesis, Serta Disertasi. CV.Alfabeta.

M. Anwar Fuadi. (2011). Dinamika Psikologis Kekerasan Seksual: Sebuah Studi Fenomenologi. Jurnal Psikologi Islam, 8(2).

Mariana, M., \& Daya, A. (2020). Penegakan Hukum Terhadap Pelaku Pelecehan 


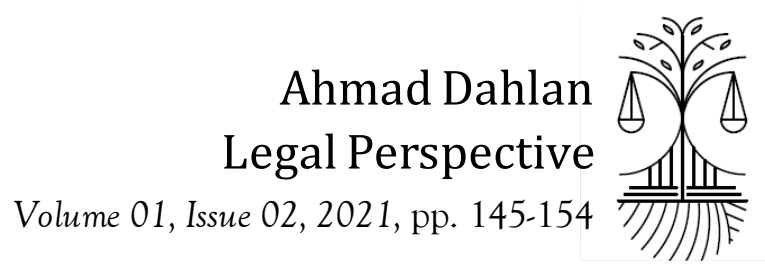

Seksual Yang Dilakukan Pengemudi Ojek Online Terhadap Penumpang. Hukum Responsif, 11(2), 101-109.

Perempuan, K. (2020). 15 Bentuk Kekerasan Seksual: Sebuah Pengenalan. Komnasperempuan.Go.Id. https://komnasperempuan.go.id/instrume nmodul-referensi-pemantauan-detail/15-bentuk-kekerasan-seksual-sebuahpengenalan

R. Soesilo. (1995). Kitab Undang-Undang Hukum Pidana (KUHP Serta KomentarKomentarnya Lengap Pasal Demi Pasal. Politeia.

Riri Novita Sari, Luluk Dwi Setiati, A. I. (2018). Perlindungan Hukum Terhadap Anak Sebagai Korban Tindak Pidana Pelecehan Seksual. LONTAR MERAH, 1(1), 19-28.

Sugiyono. (2008). Memahami Penelitian Kualitatif. Afabeta.

Suratman, \& Dillah, P. (2013). Metode Penelitian Hukum. CV.Alfabeta.

Susiana, S. (2012). Kekerasan Seksual Terhadap Perempuan di Ruang Publik. Info Singkat Kesejahteraan Sosial,IV(04), 10.

Yazid Bustomi. (2020). Efektivitas Hukum Pidana dalam Melindungi Perempuan Korban Kekerasan Seksual di Era Sekarang dan Mendatang. Nagari Law Review, 4(1), 79-91.

Yosepha Pusparisa. (2019). Transportasi Umum, Sarang Pelecehan Seksual di Ruang Publik. Databoks. https://databoks.katadata.co.id/datapublish/2019/11/28/transportasiumum-sarang-pelecehan-seksual-di-ruang-publik 